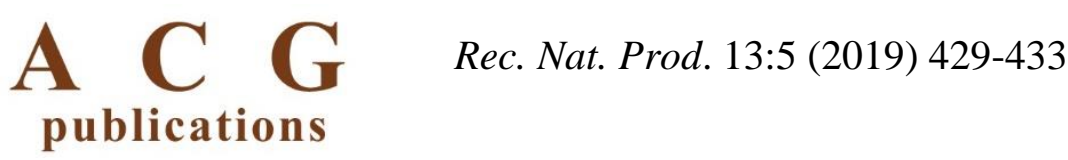

records of natural products

\title{
A New Ursane-Type Triterpene from the Roots of Salvia miltiorrhiza Bunge
}

\author{
Le Quoc Hung® 1,2, Phuong Thien Thuong®2 and Nguyen Huu Tung®1,"\# \\ ${ }^{1}$ School of Medicine and Pharmacy, Vietnam National University, Hanoi (VNU); 144 Xuan Thuy St., \\ Cau Giay, Hanoi, Vietnam \\ ${ }^{2}$ National Institute of Medicinal Materials (NIMM); 3B Quang Trung St., \\ Hoan Kiem district, Hanoi, Vietnam
}

(Received July 23, 2018; Revised September 16, 2018; Accepted September 18, 2018)

\begin{abstract}
Danshen (Salvia miltiorrhiza) is a one of the most well-known medicinal herbs in the Oriental medicine for treatment of certain cardiovascular disoders. Our current research on triterpenoid component in danshen roots led to the

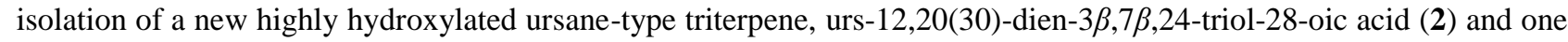
known triterpene, epiasiatic acid (1). Their structures were elucidated on the basis of extensive spectroscopic analyses including NMR and MS spectra and comparison with literature data. The new compound $\mathbf{2}$ showed medium activity against HL-60 cells with the $\mathrm{IC}_{50}$ value of $16.3 \mu \mathrm{M}$. The obtained results of unique bioactive triterpenes from danshen contributed not only to its phytochemical profile associated with chemotaxanomy but also to biological evidence of the title plant.
\end{abstract}

Keywords: Danshen; Salvia miltiorrhiza; Lamiaceae; triterpene. (c) 2019 ACG Publications. All rights reserved.

\section{Plant Source}

Salvia miltiorrhiza Bunge (Lamiaceae), commonly known as red sage or danshen, is one of the most used herbs in the Oriental medicine. Danshen is widely cultivated in China and other Asian countries including Korea, Vietnam and Australia to yield typical red roots [1,2], which are highly valuable and been used for the treatment of heart disease and improving cardio-cerebral circulation [3]. We have carried out study on phytochemical profile of danshen in Vietnam and herein report the newly results of investigation on triterpenoid constituents.

\section{Previous Studies}

Regarding phytochemical profile, a number of secondary metabolites have been identified from the title plant, revealing that nonpolar abietane-type diterpenes such as tanshinone I, tanshinone IIA, and cryptotanshinone and polar phenolic acid including salvianolic acids A-C and lithospermic acid B are the

\footnotetext{
* Corresponding author: E-Mail: tunginpc@gmail.com

\#Current address: Faculty of Pharmacy, Phenikaa University, Hanoi 100000, Vietnam and Phenikaa Research \& Technology Institute (PRATI), A\&A Green Phoenix Group, 167 Hoang Ngan, Hanoi 100000, Viet Nam
} 
principle constituents of the danshen root [4,5]. In addition, several other compounds including common sterol and triterpenes were readily reported together during the isolation procedures for the two above mentionedcompound classes and it is noteworthy that the major constituents of the aerial parts are triterpenes and be found effective on antiatherosclerosis [6]. Recently, the newly isolated compounds have been ongoing reported from danshen $[7,8]$.

\section{Present Study}

Our ongoing study on terpenoid profile of the title sample resulted in the isolation of one known compound, epiasiatic acid (1), and one new highly hydroxylated ursane-type triterpene, urs-12,20(30)-dien$3 \beta, 7 \beta, 24$-triol-28-oic acid (2). This paper deals with the isolation and structural identification of the two newly isolated triterpenes.

The air-dried danshen root sample was first extracted with EtOH- $\mathrm{H}_{2} \mathrm{O}(80: 20$, v/v) and then solvent partition procedure to obtain the EtOAc portion found to contain triterpenoid, which was followed by various column chromatography to yield the triterpenes (for the detail separation, see Supporting information, S1-S2), whose structures were elucidated on the basis of extensive physicochemical data including NMR and MS spectra together with comparison with those in the literature (Figure 1). To our knowledge, this is the first report of epiasiatic acid (1) in danshen.

Urs-12-ene-2 $\alpha, 3 \beta, 24-t r i o l-28$-oic acid (Epiasiatic acid, 1): white amorphous powder; ESI-MS: $\mathrm{m} / \mathrm{z}$ $489.2[\mathrm{M}+\mathrm{H}]^{+} ;{ }^{1} \mathrm{H}$ NMR $\left(400 \mathrm{MHz}, \mathrm{CD}_{3} \mathrm{OD}\right): \delta 5.22(1 \mathrm{H}$, br s, H-12), $3.74(1 \mathrm{H}, \mathrm{d}, J=11.6, \mathrm{H}-24 \mathrm{a}), 3.60$ $(1 \mathrm{H}, \mathrm{m}, \mathrm{H}-3 \alpha), 3.29(1 \mathrm{H}, \mathrm{d}, J=11.6 \mathrm{~Hz}, \mathrm{H}-24 \mathrm{~b}), 2.91(1 \mathrm{H}, \mathrm{d}, J=9.6 \mathrm{~Hz}, \mathrm{H}-2 \beta), 1.16\left(3 \mathrm{H}, \mathrm{s}, \mathrm{CH}_{3}\right), 1.09(3 \mathrm{H}$, $\left.\mathrm{s}, \mathrm{CH}_{3}\right), 1.00\left(3 \mathrm{H}, \mathrm{s}, \mathrm{CH}_{3}\right), 0.92\left(3 \mathrm{H}, \mathrm{s}, \mathrm{CH}_{3}\right), 0.94(3 \mathrm{H}, \mathrm{d}, J=6.0 \mathrm{~Hz}), 0.83(3 \mathrm{H}, \mathrm{d}, J=6.0 \mathrm{~Hz}) ;{ }^{13} \mathrm{C} \mathrm{NMR}(100$ $\mathrm{Hz}, \mathrm{CD}_{3} \mathrm{OD}$ ): $\delta 47.0$ (C-1), 69.1 (C-2), 85.4 (C-3), 42.6 (C-4), 49.1 (C-5), 19.0 (C-6), 33.8 (C-7), 39.6 (C-8), 48.2 (C-9), 38.6 (C-10), 23.8 (C-11), 125.9 (C-12), 138.9 (C-13), 42.6 (C-14), 28.5 (C-15), 24.9 (C-16), 48.5 (C-17), 53.5 (C-18), 39.7 (C-19), 39.5 (C-20), 31.1 (C-21), 37.6 (C-22), 22.9 (C-23), 65.8 (C-24), 17.0 (C-25), 17.3 (C-26), 26.2 (C-27), 181.1 (C-28), 17.4 (C-29), 21.4 (C-30) [9].

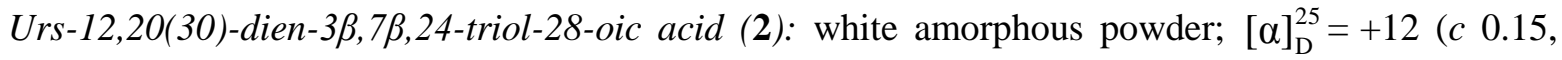
$\mathrm{CH}_{3} \mathrm{OH}$ ); HR-ESI-MS: $m / z$ 487.3431 [M + H] $]^{+}$(calcd for $\left.\mathrm{C}_{30} \mathrm{H}_{47} \mathrm{O}_{5}, 487.3423\right) ;{ }^{1} \mathrm{H}$ NMR $\left(500 \mathrm{MHz}, \mathrm{CD}_{3} \mathrm{OD}\right)$ and ${ }^{13} \mathrm{C}$ NMR (125 MHz, $\left.\mathrm{CD}_{3} \mathrm{OD}\right)$ : see Table 1.

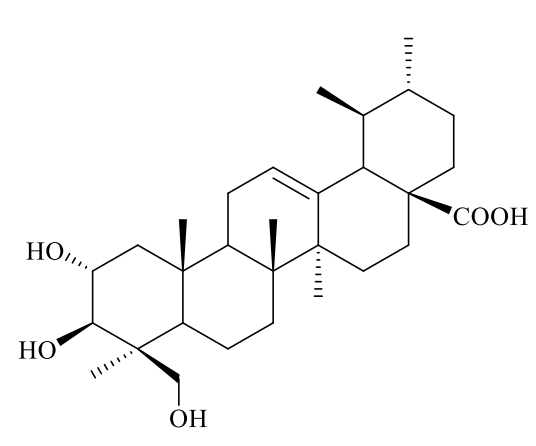

1

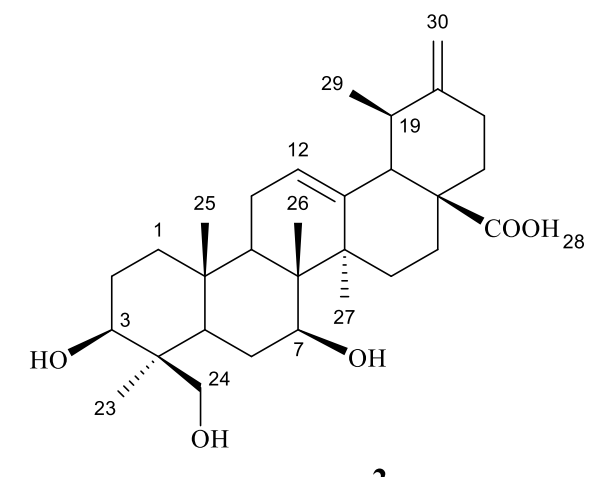

2

Figure 1. Structures of the two isolated triterpenes from the roots of S. miltiorrhiza

Compound 2 was obtained as a white amorphous powder and its molecular was determined to be $\mathrm{C}_{30} \mathrm{H}_{46} \mathrm{O}_{5}$ by HR-ESI-MS $\left(\mathrm{m} / z 487.3431[\mathrm{M}+\mathrm{H}]^{+}\right.$; calcd for $\left.\mathrm{C}_{30} \mathrm{H}_{47} \mathrm{O}_{5}, 487.3423\right)$. In consistent with those of epiasiatic acid (1), the NMR data suggested that 2 have structural features typical of an urs-12-en-28-oic acid $[10,11]$. The ${ }^{1} \mathrm{H}$ NMR spectrum detected an olefinic proton at $\delta 5.28(1 \mathrm{H}$, br t,$J=3.5 \mathrm{~Hz})$, four oxygen-bearing resonances at $\delta 3.94(1 \mathrm{H}, \mathrm{m}), 3.77(1 \mathrm{H}$, br d, $J=2.5 \mathrm{~Hz}), 3.67(1 \mathrm{H}, \mathrm{d}, J=11.5 \mathrm{~Hz})$, and $3.41(1 \mathrm{H}, \mathrm{d}, J=11.5$ $\mathrm{Hz})$, four singlet methyls $(\delta 1.22,1.13,1.00,0.86)$, and one doublet methyl at $\delta 1.02(\mathrm{~d}, J=6.0 \mathrm{~Hz})$, respectively. In addition, ${ }^{13} \mathrm{C}$ and DEPT analyses detected two olefinic carbons $(\delta 139.6$ and 126.6), three oxygenated carbons $\left(\delta 74.6 \mathrm{CH}, 67.0 \mathrm{CH}\right.$, and $\left.65.9 \mathrm{CH}_{2}\right)$, five methyl signals $(\delta 24.1,23.1,17.8,17.5,16.8)$, and one carboxylic carbon $(\delta 182.2)$, respectively. Moreover, the other proton and carbon signals assignable to rings $\mathrm{A}, \mathrm{B}, \mathrm{C}$, and $\mathrm{D}$ were in agreement with those reported for urs-12-en-3 $\beta, 7 \beta, 24$-triol-28-oic acid [12], 
whereas the signals assignable to ring E were different. The NMR spectra of 2, compared with ursolic acid, lacked a doublet methyl signal (Me-30) and contained a typical pair of germinal olefilic protons at $\delta 4.68$ and 4.63 (each $1 \mathrm{H}$, br s) in the ${ }^{1} \mathrm{H}$ NMR as well as a quaternary carbon $(\delta 155.0, \mathrm{C})$ and secondary carbon $(\delta 104.9$, $\left.\mathrm{CH}_{2}\right)$ in the ${ }^{13} \mathrm{C}$ NMR and DEPT spectra proposed an exo-methylene group $\left(>\mathrm{C}=\mathrm{CH}_{2}\right)$. The location of the exocyclic double bond at $\mathrm{C}-20$ was suggested by the absence of the Me-30 signal and confirmed by the resonances of the neighboring carbons C-18, C-19, C-21, and C-22 as well as in compatible with those of the similar molecules of urs-12,20(30)-dien-28-oic acid [13,14].

Table 1. NMR spectroscopic data (500 MHz, $\left.\mathrm{CD}_{3} \mathrm{OD}\right)$ for $\mathbf{2}$

\begin{tabular}{|c|c|c|}
\hline Position & $\delta_{\mathrm{C}}$ mult & $\delta_{\mathrm{H}}(J$ in $\mathbf{H z})$ \\
\hline 1 & $42.8, \mathrm{CH}_{2}$ & $1.61 \mathrm{~m}, 1.30 \mathrm{~m}$ \\
\hline 2 & $34.6, \mathrm{CH}_{2}$ & $1.56 \mathrm{~m}, 1.36 \mathrm{~m}$ \\
\hline 3 & 74.6, CH & 3.77 br d(2.5) \\
\hline 4 & $45.4, \mathrm{C}$ & \\
\hline 5 & $50.0, \mathrm{CH}$ & $1.35 \mathrm{~m}$ \\
\hline 6 & $19.4, \mathrm{CH}_{2}$ & $1.54 \mathrm{~m}, 1.35 \mathrm{~m}$ \\
\hline 7 & $67.0, \mathrm{CH}$ & $3.94 \mathrm{~m}$ \\
\hline 8 & $40.9, \mathrm{C}$ & \\
\hline 9 & $49.0, \mathrm{CH}$ & $1.76 \mathrm{~m}$ \\
\hline 10 & $39.2, \mathrm{C}$ & \\
\hline 11 & 24.6, $\mathrm{CH}_{2}$ & $2.03 \mathrm{~m}, 1.92 \mathrm{~m}$ \\
\hline 12 & 126.6, $\mathrm{CH}$ & 5.28 br t $(3.5)$ \\
\hline 13 & $139.6, \mathrm{C}$ & \\
\hline 14 & $43.5, \mathrm{C}$ & \\
\hline 15 & $29.4, \mathrm{CH}_{2}$ & $1.11 \mathrm{~m}, 1.03 \mathrm{~m}$ \\
\hline 16 & $25.5, \mathrm{CH}_{2}$ & $2.20 \mathrm{~m}, 1.75 \mathrm{~m}$ \\
\hline 17 & $48.5, \mathrm{C}$ & \\
\hline 18 & $56.8, \mathrm{CH}$ & $2.32 \mathrm{~d}(12.0)$ \\
\hline 19 & $38.8, \mathrm{CH}$ & $2.40 \operatorname{dd}(12.0,6.5)$ \\
\hline 20 & $155.0, \mathrm{C}$ & \\
\hline 21 & $33.5, \mathrm{CH}_{2}$ & $2.30 \mathrm{~m}, 2.20 \mathrm{~m}$ \\
\hline 22 & $40.6, \mathrm{CH}_{2}$ & $1.85 \mathrm{~m}, 1.66 \mathrm{~m}$ \\
\hline 23 & $23.1, \mathrm{CH}_{3}$ & $1.13 \mathrm{~s}$ \\
\hline 24 & $65.9, \mathrm{CH}_{2}$ & $3.67 \mathrm{~d}(11.5), 3.41 \mathrm{~d}(11.5)$ \\
\hline 25 & $16.8, \mathrm{CH}_{3}$ & $1.00 \mathrm{~s}$ \\
\hline 26 & $17.8, \mathrm{CH}_{3}$ & $0.86 \mathrm{~s}$ \\
\hline 27 & $24.1, \mathrm{CH}_{3}$ & $1.22 \mathrm{~s}$ \\
\hline 28 & $182.2, \mathrm{C}$ & \\
\hline 29 & $17.5, \mathrm{CH}_{3}$ & $1.02 \mathrm{~d}(6.0)$ \\
\hline 30 & $104.9, \mathrm{CH}_{2}$ & $4.68 \mathrm{~s}, 4.63 \mathrm{~s}$ \\
\hline
\end{tabular}

The indication of $3 \beta-\mathrm{OH}$ was evidenced by the ${ }^{1} \mathrm{H}$ NMR signal at $\delta 3.77(1 \mathrm{H}, \mathrm{br} \mathrm{d}, J=2.5 \mathrm{~Hz})$ ) and the relatively upfield ${ }^{13} \mathrm{C}$ NMR signal at $\delta 74.6[12,14]$ in conjunction with the assignment of $24-\mathrm{CH}_{2} \mathrm{OH}$ evidenced by the two typical germinal protons $[\delta 3.67(1 \mathrm{H}, \mathrm{d}, J=11.5 \mathrm{~Hz})$ and $3.41(1 \mathrm{H}, \mathrm{d}, J=11.5 \mathrm{~Hz})]$ and in respect to those of related ursane derivatives with $3 \beta, 24$-diol $[10,12]$. The proton signal at $\delta 3.94(1 \mathrm{H}, \mathrm{m})$ was typical for the oxymethin $7 \beta-\mathrm{OH}$ as evidenced by downfield-shifted resonances of respective $\mathrm{C}-6(\delta 19.4)$ and C-8 $(\delta 40.9)$, the spin coupling system of H-5- H-7 observed in the COSY spectrum, and HMBC correlations of H-5/C-7 and H-9/C-7 [12] (Figure 2). 


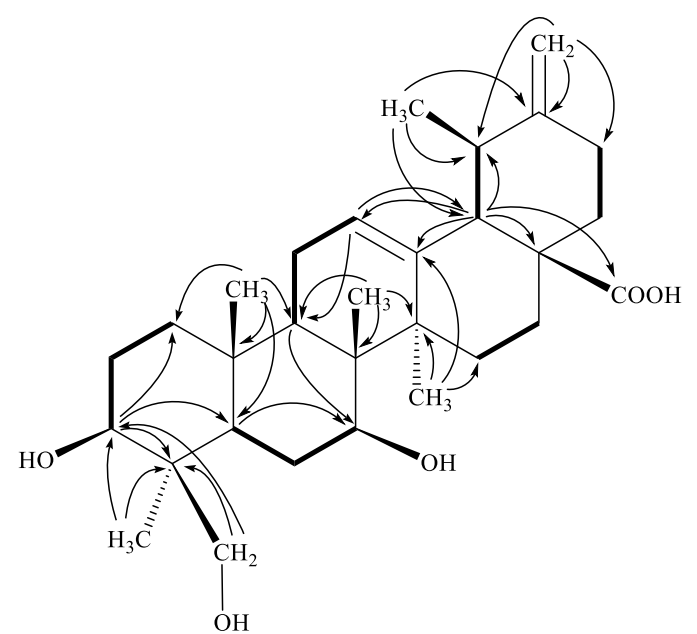

Figure 2. Key HMBC (arrow) and H-H COSY (bold line) correlations for 2

In concern of stereochemistry, the conformation between the five fused rings of the ursane skeleton is unambiguously rigid $[10,11]$. The ${ }^{1} \mathrm{H}$ and ${ }^{13} \mathrm{C}$ NMR data indicated the orientation of $3 \beta$-OH $[12,14]$, which was confirmed by the NOE correlations of $\mathrm{H}-3 \alpha / \mathrm{H}-5$ in the NOESY spectrum of 2 . The hydroxyl group at C7 was then determined as $\beta$-orientation on the basis of the NOESY correlations of $\mathrm{H}-7 \alpha / \mathrm{H}-3 \alpha, \mathrm{H}-5 / \mathrm{H}-7 \alpha$, and $\mathrm{H}-7 \alpha / \mathrm{H}-9$, while no NOESY cross-peak of $\mathrm{H}-7 / \mathrm{H}_{3}-25$ and $\mathrm{H}-7 / \mathrm{H}_{3}-26$ was observed (Figure 3 ). The full assignments of the ${ }^{1} \mathrm{H}$ NMR and ${ }^{13} \mathrm{C}$ NMR data of 2 were listed in Table 1 . Based on the above analyses, the structure of $\mathbf{2}$ was unambiguously identified urs-12,20(30)-dien-3 $\beta, 7 \beta, 24$-triol-28-oic acid (2).

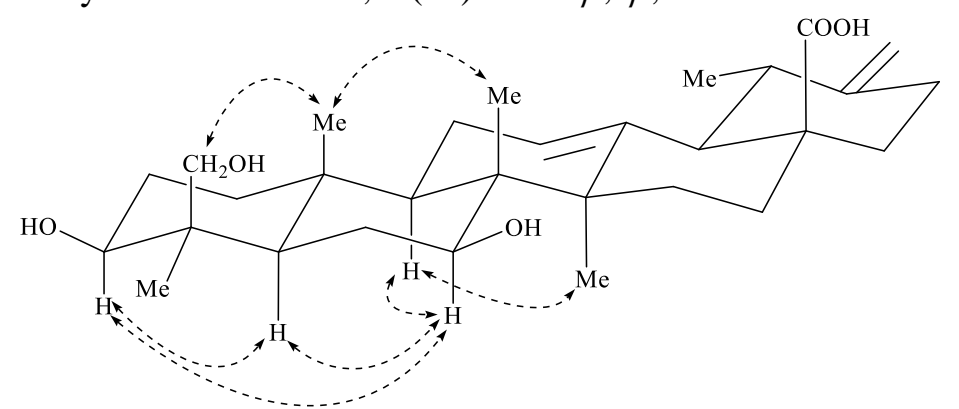

Figure 3. Stereochemistry with selected NOESY correlations of 2

Antiproliferative activity of the two isolated compounds was tested on the leukemia HL-60 cell line using the MTT assay [15,16]. As the results, while compound 1 showed negligible effect $\left(\mathrm{IC}_{50}>30 \mu \mathrm{M}\right.$, the new compound 2 exhibited medium activity with the $\mathrm{IC}_{50}$ value of $16.3 \mu \mathrm{M}$ in compared with mitoxantrone (positive control, $\mathrm{IC}_{50}=7.2 \mu \mathrm{M}$ ).

In the viewpoint of chemotaxonomy, the abundance of pentacyclic triterpenoids has been well documented from various Salvia species including oleanane, ursane, lupane, and taraxerane skeletons [17,18]. Among them, ursane and oleanane contents represent more common and highly structural diversity based on unsaturated degree and oxidized positions with hydroxyl and oxo functions in their molecules. To our knowledge, the feature of 7-OH and/or $\Delta^{20(30)}$ in the triterpene molecules from Salvia species and nature is relatively rare and, to date, only very few such derivatives have been reported including dehydrouvaol and micromeric acid from $S$. horminum, respectively [18].

In consistent with literature review of Salvia spp [5,17,18] and our researches [7], various ursane and oleane triterpenes have been identified in both aerial and root parts of danshen, and concentrated in EtOAc portion with not low yield, it appears that triterpenoid components need be cited along with hydrophobic diterpenes (tanshinones) and hydrophilic phenolic acids in the chemical profile of danshen. In conclusion, the occurrence of various ursane and oleanane triterpenes contributed in part evidence of the chemotaxonomy, biological activity and potential in medicinal use of danshen. 


\section{Acknowledgement}

This research is funded by Vietnam National Foundation for Science and Technology Development (NAFOSTED) under grant number 106-YS.05-2015.05.

\section{Supporting Information}

Supporting Information accompanies this paper on http://www.acgpubs.org/journal/records-ofnatural-products

\section{ORCID}

Le Quoc Hung: 0000-0001-8331-2859

Phuong Thien Thuong: 0000-0003-0334-379X

Nguyen Huu Tung: 0000-0001-6005-9280

\section{References}

[1] D. T. Loi (2001). Medicinal plants and ingredients in Vietnam. Vietnam Medical Publisher, Hanoi, 818-820.

[2] S. J. Sheng, E. C. Pang, C. C. Xue and C. G. Li (2009). Seasonal variations in biomarker contents in Australiangrown Salvia miltiorrhiza roots, Chem. Biodiver. 6, 551-560.

[3] L. Zhou, Z. Zuo and M. S. Chow (2005). Dansen: An overview of its chemistry, pharmacology, pharmacokinetics, and clinical use, J. Clin. Pharmacol. 45, 1345-1359.

[4] Y. Y. Xu, R. Z. Wan, Y. P. Lin, L. Yang, Y. Chen and C. X. Liu (2007). Recent advance on research and application of Salvia miltiorrhiza, Asi. J. Pharmacodyn. Pharmacokinet. 7, 99-130.

[5] B. Q. Wang (2010). Salvia miltiorrhiza: Chemical and pharmacological review of a medicinal plant, J. Med. Plants Res. 4, 2813-2820.

[6] Q. Zhang, Z. Chang, J. Yang and Q. Wang (2008). Antiatherogenic property of triterpenoids-enriched extract from the aerial parts of Salvia miltiorrhiza, Phytother. Res. 22, 1040-1045.

[7] N. H. Tung, K. Nakajima, T. Uto, N. T. Hai, D. D. Long, T. Ohta, S. Oiso, H. Kariyazono and Y. Shoyama (2017). Bioactive triterpenes from the root of Salvia miltiorrhiza Bunge, Phytother. Res. 31, 1457-1460.

[8] H. G. Choi, P. T. Tran, J. H. Lee, B. S. Min and J. A. Kim (2018). Anti-inflammatory activity of caffeic acid derivatives isolated from the roots of Salvia miltiorrhiza Bunge, Arch. Pharm. Res. 41, 64-70.

[9] X. R. Sun, H. W. Luo and T. Sakai (1992). Pentacyclic triterpenes from Salvia paramiltiorrhiza, Shoyakugaku Zasshi 46, 202-205.

[10] S. Mahato and A. Kundu (1994). ${ }^{13} \mathrm{C}$ NMR spectra of pentacyclic triterpenoids-a complication and some salient features, Phytochemistry 37, 1517-1575.

[11] S. B. Mahato, A. K. Nandy and G. Roy (1992). Triterpenoids, Phytochemistry 31, 2199-2249.

[12] K. Mazumder, E. R. O. Siwu, S. Nozaki, Y. Watanabe and K. Tanaka (2011). Ursolic acid derivatives from Bangladeshi medicinal plant, Saurauja roxburghii: isolation and cytotoxic activity against A431 and C6 glioma cell lines, Phytochem. Lett. 4, 287-291.

[13] A. Ulubelen, C. H. Brieskorn and N. Ozdemir (1977). Triterpenoids of Salvia horminum constitution of a new diol, Phytochemistry 16, 790-791.

[14] S. Passannanti, M. Paternostro and F. Piozzi (1983). Triterpene acids from Salvia and Teucrium species, Phytochemistry 22, 1044-1045.

[15] N. H. Tung, T. Uto, A. Sakamoto, Y. Hayashida, Y. Hidaka, O. Morinaga, S. Lhieochaiphant and Y. Shoyama (2013). Antiproliferative and apoptotic effects of compounds from the flower of Mammea siamensis (Miq.) T. Anders. On human cancer cell lines, Bioorg. Med. Chem. Lett. 23, 158-162.

[16] T. Mosmann (1983). Rapid colorimetric assay for cellular growth and survival: Application to proliferation and cytotoxicity assays, J. Immunol. Methods 65, 55-63.

[17] G. Topcu (2006). Bioactive triterpenoids from Salvia species, J. Nat. Prod. 69, 482-487.

[18] S. K. Jash, D. Gorai and R. Roy (2016). Salvia genus and triterpenoids, Int. J. Pharm. Sci. Res. 7, 4710-4732.

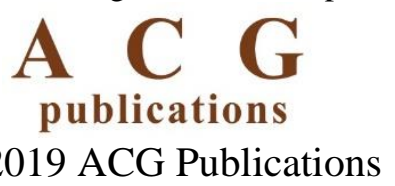

